DOI https://doi.org/10.18551/rjoas.2017-02.18

\title{
THE EFFECT OF CULTURE AN BEHAVIOR OF LEADERS TOWARD EMPLOYEE PERFORMANCE: A STUDY ON SAVINGS AND LOAN COOPERATIVES IN PAPUA, INDONESIA
}

\author{
Sarminanto*, Hadiwidjojo Djumilah, Djumahir, Rahayu Mintarti \\ Faculty of Economy and Business, University of Brawijaya, Indonesia
}

*E-mail: sarminanto65@gmail.com

\begin{abstract}
Cooperatives in Papua are not only facing competition at the local level, but also facing competition with economic institutions at the global level. In order to compete as a modern economic institution, the performance of cooperatives needs to be improved in order to successfully become globalized economic institutions. The decline in the performance of cooperatives in Papua is thought to be caused by a factor of organizational culture and behavior of cooperative leaders. This study aims (1) to test and analyze the influence of organizational culture on employee performance and (2) to examine and analyze the effect of behavior of leaders on employee performance. This study was conducted at some research sites in five (5) regencies and one (1) city in the Province of Papua. The sampling technique sampling used was area sampling. The population was all employees of cooperatives. These employees have been actively working for more than five (5) years. There were as many as 252 employees in 120 cooperatives. Since the total population was only 252 people, the study used a saturated sample technique or population research. Quantitative analysis method used was Structural Equation Modeling (SEM). The results of the study are as follows. First, culture directly and significantly affects employee performance. Second, the behavior of leaders directly and significantly affects employee performance.
\end{abstract}

\section{KEY WORDS}

Culture, behavior, leader, employee, performance.

For such a long time, cooperatives have been considered unimportant. They are seen merely as a collection of people who are completely weak. People tend to think that cooperatives do not play any roles, compared to medium and even large private business. This is completely wrong, yet the thought has long stayed in our mind. In Indonesia, some cooperatives actually have had large and diverse business units and have grown into a large-scale business dominating the life of many people in various areas of commercial enterprises. Cooperatives turnover has reached billions of rupiah per month. However, as Bung Hatta said, "Despite the great business, cooperatives which have not been able to prosper the life of the members cannot be said as a real cooperative; cooperatives shall work for the interests of the members." In the Province of Papua, there are 2,483 cooperatives nowadays. However, only 1,460 cooperatives or about $58 \%$ are active, while the remaining 1,023 or about $42 \%$ of cooperatives are inactive needing to be addressed so as not to close down (Tempo, July 18, 2013). In general, the growth of cooperatives in Papua from the aspect of quantity increases, but the number of cooperatives facing problems is also increasing.

Article 3 Law Number 25 of 1992 states that the purpose of cooperatives is to promote the welfare of members in particular and society in general as well as to help build national economy in order to realize an advanced equitable and prosperous society based on Pancasila and the Constitution of 1945. The results of the preliminary study showed that the performance of cooperatives in Papua was still not optimal. Data released by Tempo on July 18,2013 proved that as many as $42 \%$ of cooperatives in Papua were inactive. This data can be interpreted as the sign of low performance of many cooperatives in Papua. The assumption built from the results of preliminary study is that the low performance of 
cooperatives in Papua is due to the performance of managers of cooperatives, in this case is the leaders and employees of cooperatives in Papua. The decline in the performance of cooperatives in Papua is thought to be caused by the presence of organizational culture, as well as the behavior of the leaders and employees. It has been assumed that cooperative organizational culture in the form of creative work culture, culture of learning, and work ethic have not been practiced as expected and eventually have led to low employee performance. Behavior of cooperative leaders in the form of care to employees, communication with employees, participation in performing tasks, and spirit to succeed in managing the cooperative is still low so the motivation and performance is also low.

The view above shows that cooperatives need to have an organizational culture that supports the achievement of organizational goals. Organizational culture within cooperatives refers to the basic patterned assumption found, explored, and developed by a group of people as the experience to solve problems, adapt to external factors and internal integration (Schein 1992). Strong organizational culture supports its members to understand how to carry out tasks and give stability to the organization (Robbins and Judge, 2007). Organizations are intimately associated with leadership behavior. Leadership has become one of the key factors in organizational life. Organizations need a leader to carry out the tasks that focus on common goals (Hadari and Martini, 2006). The behavior of the leaders will be a role model for employees, because employees see how the behavior of the leaders could fit in with their plans to work and contribute to the organization.

Based on the background and reasoning as described above, then it is important and useful to analyze and examine whether organizational culture and leadership behaviors can improve employee performance in the savings and loan cooperatives in the Province of Papua.

\section{LITERATURE REVIEW}

Wilson (2009) examines the influence of organizational culture on employee performance. The study is conducted at a company having employees more than 5000 people. In this study, the performance of employees becomes the dependent variable and organizational culture becomes the independent variable that is determined by the interaction of internal and external forces. Internal forces consist of a sense of achievement of development and advancement, nature of work, and recognition. While external forces consist of company policy and supervision.

Van den Berghe (2004) conducts a study to reveal the influence of behavior of leaders on employee motivation at Toyota Kijang insurance. The study involves 104 respondents owners of Toyota Kijang. The study has found a positive and significant relationship between leadership behavior and motivation of employees.

Research by Wilson (2009) shows that the performance of employees is affected by organizational culture. The result indicates that internal forces, which consist of a sense of achievement of development and advancement, nature of work, and recognition, affect performance. While external forces, which consist of company policy and supervision, also affect performance. Compared with Wilson's study (2009), this study is different in the form of the three indicators used. Wilson's study uses (1) a sense of achievement of development and advancement, (2) the nature of work and (3) recognition as the indicators, while this study uses (1) creativity, (2) learning and (3) ethics as the indicators. Besides, Wilson's study (2009) uses organizational culture as an independent variable, and employee performance as the dependent variable.

Luthans (2006) and Hellriegel (1998) argue that organizational culture has a number of important characteristics as follows: (1) routine behavior when members interact; (2) the norms adopted by the working group throughout the organization; (3) the dominant values held by members of the organization; (4) the direction of organization's policy for employees and customers; (5) the rules to build relationship among colleagues in the organization that must be received by employees; and (6) feelings or climatic delivered in an organization with the physical layout and the way in which members of the organization interact with external 
parties.

Fiedler (1967, in Vromm and Jago (2007) also explains that leadership is basically a pattern of relationships between individuals using the authority and influence of the group of people to work together to achieve goals. This opinion is also supported by Pfiffner (1977), which states that leadership is the ability to coordinate and motivate people and groups to achieve the desired goals. In line with the two opinions above, Davis (1977) defines leadership is the ability to invite others to achieve the stated goals vigorously.

Sutrisno (2011) suggests that performance is the result of work that can be achieved by a person or group of people in an organization, in accordance with the authority and responsibilities of each, in an effort to achieve the goals of the organization legally and in accordance with moral and ethics. Wirawan (2009) sees performance as the output produced by functions or indicators of a job or a profession in a given time.

\section{CONCEPTUAL FRAMEWORK}

This conceptual framework describes the relationship between the study variables. Relationship between variables is based on the theory of organizational culture, behavior of leaders, and employee performance. The results of research is related to the relationship between the theory of organizational culture and leadership behavior toward performance. Based on the relationship of variables based on theories and previous research, the conceptual framework of the study is then prepared.

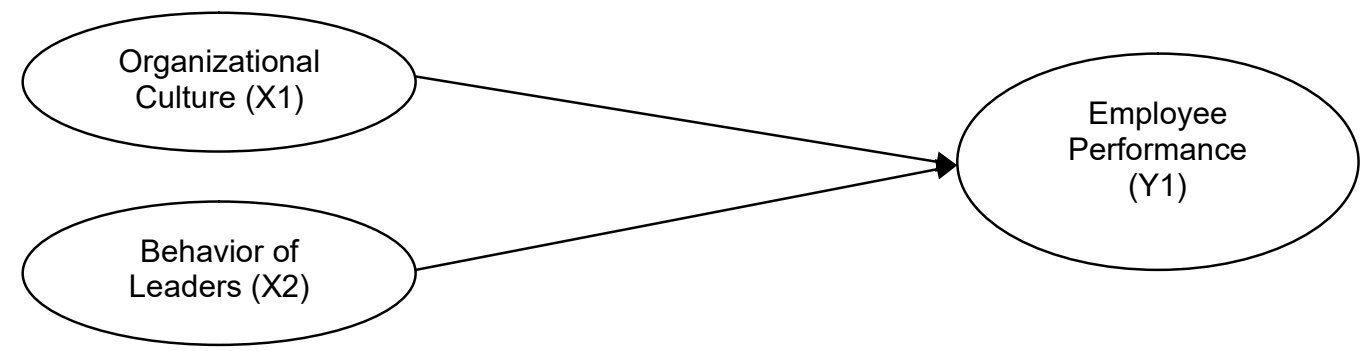

Figure 1 - Relationship between Variables

Research Hypotheses. Research conducted by Maran (2010), Inamete (2009), Fritzsche (1994), Tziner (2011), and Pinder and Harlos (2001) find the positive and significant relationship of organizational culture and employee performance. Organizational culture and behavior of leaders can have various effects on employee performance. Employees work harder to achieve the goals of the organization if they think of themselves as part of the organization and its culture. Different cultures in one organization may also affect the performance of employees; this indicates a real gap, so the first hypothesis of the study is as follows:

$\mathrm{H} 1$ : Organizational culture is able to influence employee performance.

The basic underlying this hypothesis is the theoretical study conducted by Abasi (2012), Atmojo (2012), and Eagleson et al. (2000). The studies have found the positive and significant relationship between behavior of leaders and employee performance. Organizations use strategic reward system to motivate employees and improve their performance. Thus, the second hypothesis of the study is as follows:

$\mathrm{H} 2$ : The behavior of leaders is able to influence performance of employees.

Operational Definition:

Organizational Culture $(X 1)$. Organizational culture as a variable $(X 1)$, is then given a code (BO), refers to the interaction of traits and habits that affect groups of people in their environment. Habits that support the organizational culture are creative culture, willingness to learn from the success of others, ethics or manners, and traditions in an organization. This statement is supported by the previous studies of Maran (2010), Inamete (2009), and Fritzsche (1994). From the above statement, the indicators proposed in this study are as 
follows: creativity, learning, and ethics.

Behavior of Leaders (X2). Behavior of leaders as a variable (X2) is then given a code (PP), refers to real action done by a leader. In doing actions, leaders cannot be separated from their behavior (Almansour, 2012; Kumar, Anjum, and Sinha, 2011). Indicators of behavior of leaders that are used in this study are based on the statement put forward by Al Mansour (2012), Kumar, Anjum, and Sinha (2011). From the above statement, the indicators proposed in this study are as follows: reward to employees, communication, participation, and achievement.

Employee Performance $(\mathrm{Y} 1)$. Employee performance as a variable $(\mathrm{Y})$, is then given a code (KJ), refers to the level of achievement and the understanding on the positive and negative impacts of an operational policy (Wright, 2002). Employee performance indicators used in this study are based on the concept proposed by Bernardin and Russel (1993), Armstrong (2004), Bass (2003), and Kasali (2001). The indicators used are as follows: the quality of work, the quantity of work, and the mental attitude of work.

\section{METHODS OF RESEARCH}

The study took places in five (5) regencies and one (1) city in Papua, namely (1) the City ofJayapura, (2) the Regency of Jayapura, (3) the Regency of Jayawijaya, (4) the Regency of Timika, (5) the Regency of Biak Numfor, and (6) the Regency of Merauke. The sampling technique sampling used was area sampling. The population was all employees of cooperatives. These employees have been actively working for more than five (5) years. There were as many as 252 employees in 120 cooperatives. Since the total population was only 252 people, the study used a saturated sample technique or population research. Quantitative analysis method used was Structural Equation Modeling (SEM) to examine the causal relationship between variables. Solimun (2008) states that SEM consists of Measurement Model and Structural Model analyzed using AMOS 10.4 (Analysis of Moment Structure).

\section{RESULTS AND DISCUSSION}

Hypothesis 1: Organizational culture is able to influence employee performance.

The results of analysis show a positive correlation with a parameter coefficient of 0.57 and significant correlation between organizational culture (X1) and employee performance (Y) because the t statistic (4.201) is greater than t table (1.960). It can be concluded that there is a positive and significant influence of cultural organization (X1) on employee performance $(\mathrm{Y})$. Positive sign means that the stronger cultural organization (X1), the higher the employee performance (quantity, quality, and professional attitude) will be; in other words, the more powerful creative communication, learning, and cooperation will be. The level of confidence of the relationship is $(100 \%-0 \%)$ or equal to $100 \%$. In the context of research on savings and loan cooperatives in the province of Papua, organizational culture refers to perceptions of employees and how the perception creates a pattern of beliefs, values, and expectations, as has been said by Schein (1992). The results of this study also confirm the opinion of Gibson et al. (2012) which states that organizational culture is the perception of employees and how their perceptions pattern form beliefs, values, and expectations; thus, organizational culture has a number of important characteristics as stated by Luthans (2006) and Hellriegel (1998).

Hypothesis 2: The behavior of leaders is able to influence performance of employees.

The results of the analysis show a positive and significant correlation between behavior of leaders and employee performance, with alpha of $5 \%$. Positive sign means that the stronger behavior of leaders (X2), the higher the employee performance will be. The level of confidence of the relationship is $(100 \%-0 \%)$ or equal to $100 \%$. This study can explain that behavior of leaders has an important role, as it is an example for employees of cooperatives. The existence of the good example provides encouragement for employees to follow the example given in carrying out the work. Leadership is an effort to use the kind of influence rather than coercion to motivate people through communication in order to achieve certain goals (Gibson 
et al., 2012). This study supports the opinion of Gibson et al. (2012). Leadership is also interpreted as the ability to influence a group to achieve certain goals (Robbins and Judge, 2007); this opinion is also evidenced in this study. Based on this study and compared with previous studies, it can be affirmed that behavior of leaders has an influence on employee performance. The behavior of leaders in cooperatives in Papua has been appropriate to have a good impact on employee performance. The behavior of the leaders playing the biggest role in affecting employee performance is achievement - the leaders are able to establish a good relationship with the employees, so employees are willing to run the job happily, and therefore could produce better performance.

Limitation. The study took places in five (5) regencies and one (1) city in Papua, while Papua has 20 cities and regencies and has about 600 savings and loan cooperatives. The subjects of this study were only 240 respondents, so it does not reflect the overall population, as there are more than a thousand respondents in all savings and loan cooperatives in Papua. Further studies must be done by increasing the number of research sites in locations that have not been studied.

\section{Conclusion}

The results of this study indicate that organizational culture by cooperatives Papua can bring an impact on employee performance. The organizational culture that plays the biggest role is learning, where learning for employees need to be developed so cooperatives in Papua can develop even faster and better.

The behavior of leader in cooperatives in Papua can bring an impact on employee performance. The behavior of leaders that plays the biggest role in supporting employee performance is achievement, i.e. the behavior of leaders that can provide challenges, seeks improved performance, emphasizes on performance, and shows confidence that employees will achieve high standards.

\section{SUGGESTIONS}

Organizational culture, despite being able to promote employee performance, still needs to be improved, especially with regard to ethics. Cooperative management needs to improve employee ethics, i.e. the values and norms of employees in the work. Cooperative management can regularly conduct trainings or regular meetings to establish the values of good work for employees. Cooperative management may also send employees to attend trainings to improve the ethics of employees in the work.

The behavior of the leaders still needs to be improved, as leadership in cooperatives in Papua is still not strong enough. Leadership of cooperative management still needs to be improved, and this can be done by sending cooperative managers to attend leadership training conducted by government agencies and universities. Cooperatives may also propose to the provincial and city governments to conduct leadership training for cooperative managers.

\section{REFERENCES}

1. Abbasi, A.S. 2012. The Effectiveness of Leadership, Performance, and Employee Involvement for Producing Competitive Advantage with a TQM Orientation: a Conceptual Framework. Mediterranean Journal of Social Sciences, Vol 3, pp. 83-90.

2. Almansour, Y.M. 2012. The Relationship Between Leadership Styles and Motivation of Managers Conceptual Framework. Researcher Word. Journal of Art, Science and Commerce. Vol. 3, pp. 161-166.

3. Armstrong, M. 2004. Performance Management. Tugu Publisher. Jakarta

4. Atmojo, M. 2012. The Influence of Transformational Leadership on Job Satisfaction, Organizational Commitment, and Employee Performance. International Research Journal of Business Studies, 5(2): 113-128. 
5. Bass, B.M. 2003. Developing Culture Organizational. Management Applications. New York: The Free Press.

6. Bernardin, H.J., and Russell, J.E.A. 1993. Human resource management: An experiential approach. McGraw-Hill. Singapore

7. Davis, K. and Newstrom. 1977. Perilaku Dalam Organisasi, Edisi ketujuh, Penerbit Erlangga, Jakarta

8. Eagleson, G., Waldersee, R., and Simmons, R. 2000. Leadership Behavioor similarity as a basis of Selection into a management team. British Journal of Social Psychology, Vol 39.pp. 301-308.

9. Fiedler, F.E. 1967. A Theory of Leaderships Effectiveness, Mc Graw-Hill Book Company, New York, p.159.

10. Fritzsche, D.J. 1994. Corporate Culture and Performance. Bus. and Society Journal, 327.

11. Gibson, J.L., Ivancevich, J.M., Donnelly, Jr. J.H., and Konopaske, R. 2012. Organizations: Behavior, Structure, Processes. Fourteenth Edition. McGraw-Hill. New York

12. Hadari, N. and Martini, M. 2006. Kepemimpinan Yang Efektif. Cetakan Kelima. Gadjah Mada University Press, Yogyakarta.

13. Hellriegel, D., Slocum Jr., J.W., Woodman, R. 1998. Organizational Behavior. Palo Alto: South Western College Publishing.

14. Inamete, U.B. 2009. Organizational Culture: A Taxonomy and a Theoretical Framework. Ideaz, (8): 8-24.

15. Kumar, R., Anjum, B., and Sinha, A. 2011. Cross-Cultural Interaction and Leadership Behaviour. Researcher Word. Vol II, July, pp. 151-160.

16. Luthans, F. 2006. Organizational Behavior. Seventh Edition, Mcgraw-Hill, Inc. Boston

17. Maran, D.A. and Soro, G. 2010. The Influence of Organizational Culture in Women Participation and Inclusion in Voluntary Organizations in Italy. Voluntas (21) pp. 481-496.

18. Pfiffner, M.J. \& Presthus, R. 1977. Public Administration. New York: Ronald Press

19. Pinder and Harlos. 2001. Employee performance, culture organizational about the individual behavioural. Journal of Applied Psychology, pp. 229 -232.

20. Kasali, R. 2001. Membidik Pasar Indonesia: Segmentasi, Targeting, dan Positioning. PT Gramedia Pustaka Utama, Jakarta. HIm 51.

21. Robbins, S.P.\& Judge. 2007. PerilakuOrganisasi. Salemba Empat, Jakarta.

22. Schein, E.H. 1992. Organizational Culture and Leadership. Jossey Bass, San Francisco.

23. Solimun. 2008. Memahami Metode Kuantitatif Mutakhir: Structural Equation Modeling \& Partial Least Square. Program Studi Statistika FMIPA Universitas Brawijaya.

24. Sutrisno, E. 2011. Budaya Organisasi, Edisi 2. Kencana Pranada. Jakarta.

25. Tziner, A. 2011. Organizational Perceptions, Leadership and Performance in Work Setting: Do They Interelate? Colegio Oficial de Psicologos de Madrid, (27). pp. 205-211.

26. Vroom, V.H. and Jago, A.G. 2007. The Role of the Situation in Leadership. American Psychological Association. Vol. 62, No. 1, pp. 17-24

27. Wirawan. 2007. Budaya dan Iklim Organisasi: Teori, Aplikasi dan Penelitian. Salemba. Jakarta.

28. Wright, C. 2002. A Motivate Performance for Organizational. Journal of Applied Psychology 43 (3), 223-228. 